\title{
Factors Associated with the Behavior of Men who Have Sex with Men in the Prevention of Human Immunodeficiency Virus Transmission
}

\author{
Purwaningsih Purwaningsih $^{1 *}$, Talia Puspita Adianti ${ }^{2}$, Sylvia Dwi Wahyuni ${ }^{1} \mathbb{D}$, Hidayat $_{\text {Arifin }}^{3}$ \\ ${ }^{1}$ Department of Fundamental Nursing, Faculty of Nursing, Universitas Airlangga, Surabaya, Indonesia; ${ }^{2}$ Faculty of Nursing, \\ Universitas Airlangga, Surabaya, Indonesia; ${ }^{3}$ Department of Medical-Surgical Nursing, Faculty of Nursing, Universitas \\ Padjadjaran, Bandung, Indonesia
}

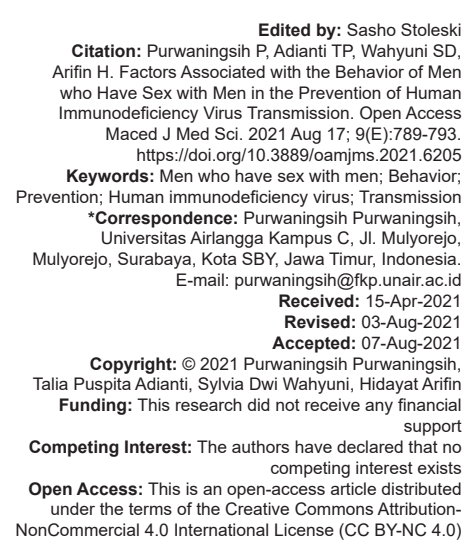

Introduction

Human immunodeficiency virus (HIV) is a disease that attacks the human immune system which affects its level of performance in the body. The infection caused by HIV can rapidly progress to the deadly acquired immune deficiency syndrome (AIDS) [1]. Health problems are caused by a condition that puts the person at risk, such as sexual behavior. This behavior results in the transmission of HIV to key populations and a high risk of becoming infected with HIV in the next few years [2]. One of the key populations that are at high risk of contracting HIVIAIDS is men who have sex with men (MSM) by as much as $21 \%$. This is because most of them change sexual partners without using condoms and lubricant and perform oral and anal sex unprotected [3]. This allows for the easy transmission of HIV to other people through sexual transmission and sexual contact.

MSM account for $57 \%$ of new HIV infections in West Europe and North America with an increase in HIV infections reaching 8-17\%. The HIV prevention strategy of condom use is only taken up by $13-16 \%$ rather than the $20-23 \%$ standard [4]. Indonesia is the fifth country in Asia in terms of the high risk of contracting HIV with the standard of HIV prevention behavior in MSM at $20-40 \%$ rather than the standard set of $70-89 \%$ [5]. The highest percentage was reported in the 25-49 age group with $70.2 \%$ HIV ratio among men and women by $2: 1[3]$.

A previous study showed that the transmission of HIV among MSM can be influenced by many factors, namely, a lack of knowledge, age, and the unavailability of condoms [6], [7], [8], [9]. In this study, researchers used the theoretical approach of Green and Kreuter [10] regarding a peer support and health education approach. This needs to be done because of the association between teenagers and unsafe sexual intercourse, such as not using condoms.

The low use of condoms and the lack of HIVIAIDS prevention measures by MSM have necessitated a change in health behavior. Health behavior is a form of activity to maintain and improve health, which can be both observed directly or cannot be observed [11]. In an effort to launch a government program to reduce the prevalence of HIVIAIDS in the MSM population, the main activity of the government 
targeted $80 \%$ of the key population, namely, MSM. This means that they can implement the program effectively. It is expected that as a result, $60 \%$ of MSM will behave in a healthy manner using condoms [12]. Risky sexual behavior conducted by MSM is still concerning. It is necessary to determine the factors of MSM behavior in relation to HIV transmission. This needs to be done to be able to determine further policies.

\section{Materials and Methods}

\section{Study design}

A cross-sectional study was undertaken.

\section{Setting and sample}

This study was conducted from April to June 2019 in the MSM community in Surabaya, Indonesia. This research was conducted by determining the reachable population of 315 respondents which was then screened based on the inclusion and exclusion criteria determined by the researcher. The respondents then gave their informed consent as evidence of their willingness to participate in the study. The total sample in this study was 176 respondents determined based on purposive sampling. The inclusion criteria were MSM aged 25-55 years old, having a partner (male or female) and MSM that have been identified as being HIV positive. The exclusion criteria were respondents who were unable to follow through with the research process up to the point of completion and/or those suffering from an illness who were required to be hospitalized.

\section{Variables}

\section{Independent variables}

The demographic data in this study were the age of the respondent divided into three categories, namely, 25-35 years old, 36-45 years old, and 46-55 years old. The education level variable consisted of four categories, namely, elementary school, junior high school, senior high school, and university. Furthermore, marriage was divided into three categories, namely, married, not married, and partnered. The length of their HIV diagnosis was divided into two categories, namely, $<1$ year and more than 1 year.

The researcher was adopted the knowledge questionnaire from Adanan [13], Pratama [14]. The questionnaire consisted of 10 items using a nominal scale of "yes" and "no." The score was divided into three categories (good: 76-100\%, moderate: 75-56\%, and poor: $\leq 55 \%)$. The validity and reliability test selected was Cronbach's alpha with a score of 0.920 . The attitude questionnaire was adopted from Basen and Fisher [15], Kambu [16]. The questionnaire consisted of nine question items measured using a Likert scale (strongly agree-strongly disagree). The score was divided into two categories (good: $\geq 25$ and less $<25$ ). Validity and reliability were determined using Cronbach's alpha with a score of 0.762 . The belief questionnaire was adopted from Shively et al. [17]. The questionnaire consisted of 19 items measured using a Likert scale (very surenot sure). The score was divided into three categories (good: $76-100 \%$, moderate: $75-56 \%$, and less: $\leq 55 \%$ ). The validity and reliability test selected was Cronbach's alpha with a score of 0.737 .

The questionnaire on the accessibility of the health facility was adopted from Irianti [18]. The questionnaire consisted of three items using a nominal scale of "yes" and "no" with two categories (affordable: $>50 \%$ and not affordable: $\leq 50 \%$ ). The validity and reliability test selected was Cronbach's alpha with a score of 0.671 . The health-related skills questionnaire was adopted from Puspah [19]. The questionnaire consisted of five items using a Likert scale (alwaysnever). The score was divided into three categories (good: 76-100\%, moderate: $75-56 \%$, and less: $\leq 55 \%$ ). The validity and reliability test selected was Cronbach's alpha with a score of 0.671 . The peer support questionnaire was adopted from Puspah [19], Holliday [20]. The questionnaire consisted of four items using a Likert scale (always-never). The score was divided into three categories (good: 76-100\%, moderate: $75-56 \%$, and less: $\leq 55 \%$ ). The validity and reliability test selected was Cronbach's alpha with a score of 0.812 . The health-care provider support questionnaire was adopted from Putri [21]. The questionnaire consisted of six items using a nominal scale of "yes" and "no." The score was divided into two categories (good: $51-100 \%$ and less: $\leq 1-50 \%$ ). The validity and reliability test selected was Cronbach's alpha with a score of 0.614 .

\section{Dependent variable}

The prevention of HIV transmission questionnaire was adopted from Bare and Smeltzer [1], Kambu [16]. The questionnaire consisted of eight items using a nominal scale of "yes" and "no." The score was divided into two categories (good: $\geq 60 \%$ and less: $<60 \%$ ). The validity and reliability test selected was Cronbach's alpha with a score of 0.634 .

\section{Data analysis}

The data analysis process in this study was assisted by the STATA 16.1 version software. The analysis used Chi-square and binary logistic regression with a confidence interval $(\mathrm{Cl})$ of $95 \%(0.05)$. 


\section{Ethical considerations}

This research was declared to have passed the ethical test from the Health Research Ethics Commission in the Faculty of Nursing of Universitas Airlangga, Indonesia, with number 1493-KEPK.

\section{Results}

The demographic characteristics of the respondents showed that most of the respondents were aged 25-35 years old whose latest level of education was that of senior high school. The marital status characteristic indicated that more than $50 \%$ of respondents were unmarried and that they'd had a diagnosis of HIV for <1 year (Table 1).

Table 1: Demographic characteristics of the respondents ( $n=176)$

\begin{tabular}{lll}
\hline Characteristics & $\mathrm{n}$ & $\%$ \\
\hline Age & & \\
25-35 years old & 103 & 58.52 \\
$36-45$ years old & 58 & 32.95 \\
46-55 years old & 15 & 8.52 \\
Level of education & & \\
$\quad$ Elementary school & 3 & 1.70 \\
$\quad$ Junior high school & 20 & 11.36 \\
$\quad$ Senior high school & 98 & 55.68 \\
$\quad$ University & 55 & 31.25 \\
Marital status & 52 & 29.55 \\
$\quad$ Married & 107 & 60.80 \\
$\quad$ Not married & 17 & 9.66 \\
$\quad$ Partner & 117 & 66.48 \\
Time since HIV diagnosis & 59 & 33.52 \\
$\quad<1$ year & & \\
More than 1 year &
\end{tabular}

The results show that most respondents engaged in the prevention of HIVIAIDS transmission in the moderate category and that almost $70 \%$ of respondents had good knowledge about HIVIAIDS. This study also shows that most respondents have a good attitude, good beliefs, and indicate that the accessibility of the health facility is affordable. The respondents in this study also have good health-related skills, peer support, and health-care providers (Table 2).

The results of the bivariate analysis using Chi-square show that the variables length of time since HIV diagnosis, knowledge, the accessibility of the health facility, peer support, and health-care support have a significant relationship with the prevention of HIV transmission. However, the variables of age, level of education, marital status, attitude, beliefs, and healthrelated skills did not have a significant relationship with prevention of HIVIAIDS transmission (Table 3).

The results of the multivariate analysis using ordinal regression logistic showed that knowledge and peer support had a significant relationship with the prevention of HIV transmission. The respondents with moderate knowledge about HIV were 1171 times more likely to engage in HIV transmission prevention (p: 0.002; odds ratio [OR]: $1.171 ; \mathrm{Cl}: 0.414,1.929)$. The respondents with less peer support were 1902 times
Table 2: Description of the variables $(n=176)$

\begin{tabular}{lll}
\hline Characteristics & $\mathrm{n}$ & $\%$ \\
\hline Prevention & 76 & \\
Good & 77 & 43.18 \\
Moderate & 23 & 43.75 \\
Less & & 13.07 \\
Knowledge & 123 & 69.89 \\
$\quad$ Good & 45 & 25.57 \\
Moderate & 8 & 4.55 \\
Less & & \\
Attitude & 135 & 76.70 \\
Good & 41 & 23.30 \\
Less & & \\
Beliefs & 115 & 65.34 \\
Good & 59 & 33.52 \\
Moderate & 2 & 1.14 \\
Less & & \\
Accessibility of the health facility & 169 & 96.02 \\
Affordable & 7 & 3.98 \\
Not affordable & & \\
Health-related skills & 132 & 75.00 \\
Good & 41 & 23.30 \\
Moderate & 3 & 1.70 \\
Less & & \\
Peer support & 102 & 57.95 \\
Good & 60 & 34.09 \\
Moderate & 14 & 7.95 \\
Less & & 87.50 \\
Health-care provider support & 154 & 7.95 \\
Good & 14 & 4.55 \\
Moderate \\
Less & 8 & \\
\hline & & \\
\hline & &
\end{tabular}

more likely to do engage in preventative HIVIAIDS transmission (p: 0.002; OR: 1.902; Cl: 0.721, 3.082). However, the respondent's ability to reach the health facilities and health-care support did not have a

Table 3: Bivariate analysis $(n=176)$

\begin{tabular}{|c|c|c|c|c|c|c|c|c|}
\hline \multirow[t]{3}{*}{ Variables } & \multicolumn{6}{|c|}{ Prevention of HIVIAIDS transmission } & \multirow[t]{3}{*}{$\mathrm{p}$} & \multirow[t]{3}{*}{$x^{2}$} \\
\hline & \multicolumn{2}{|c|}{ Good } & \multicolumn{2}{|c|}{ Moderate } & \multicolumn{2}{|c|}{ Less } & & \\
\hline & $\mathrm{n}$ & $\%$ & $\mathrm{n}$ & $\%$ & $\mathrm{n}$ & $\%$ & & \\
\hline \multicolumn{9}{|l|}{ Age } \\
\hline $25-35$ & 40 & 22.73 & 47 & 26.70 & 16 & 9.09 & \multirow[t]{3}{*}{0.207} & \multirow[t]{3}{*}{5.89} \\
\hline $36-45$ & 28 & 15.91 & 23 & 13.07 & 7 & 3.98 & & \\
\hline $46-55$ & 8 & 4.55 & 7 & 3.98 & 0 & 0 & & \\
\hline \multicolumn{9}{|l|}{ Level of education } \\
\hline Elementary school & 1 & 0.57 & 1 & 0.57 & 1 & 0.57 & \multirow[t]{4}{*}{0.805} & \multirow[t]{4}{*}{3.03} \\
\hline Junior high school & 9 & 5.11 & 7 & 3.98 & 4 & 2.27 & & \\
\hline Senior high school & 43 & 24.43 & 45 & 25.57 & 10 & 5.68 & & \\
\hline University & 23 & 13.07 & 24 & 13.64 & 8 & 4.55 & & \\
\hline \multicolumn{9}{|l|}{ Marital status } \\
\hline Married & 19 & 10.80 & 24 & 13.64 & 9 & 5.11 & \multirow[t]{3}{*}{0.324} & \multirow[t]{3}{*}{4.65} \\
\hline Not married & 51 & 28.98 & 46 & 26.14 & 10 & 5.68 & & \\
\hline Partner & 6 & 3.41 & 7 & 3.98 & 4 & 2.27 & & \\
\hline \multicolumn{9}{|l|}{$\begin{array}{l}\text { Time since HIV } \\
\text { diagnosis }\end{array}$} \\
\hline$<1$ year & 46 & 26.14 & 50 & 28.41 & 21 & 11.93 & \multirow[t]{2}{*}{0.022} & \multirow[t]{2}{*}{$7.65^{\star *}$} \\
\hline More than 1 year & 30 & 17.05 & 27 & 15.34 & 2 & 1.14 & & \\
\hline \multicolumn{9}{|l|}{ Knowledge } \\
\hline Good & 63 & 35.80 & 51 & 28.98 & 9 & 5.11 & \multirow[t]{3}{*}{0.001} & \multirow[t]{3}{*}{$17.65^{\star \star \star}$} \\
\hline Moderate & 12 & 6.82 & 21 & 11.93 & 12 & 6.82 & & \\
\hline Less & 1 & 0.57 & 5 & 2.84 & 2 & 1.14 & & \\
\hline Attitude & & & & & & & & \\
\hline Good & 60 & 34.09 & 61 & 34.66 & 14 & 7.95 & 0.156 & 3.71 \\
\hline Less & 16 & 9.09 & 16 & 9.09 & 9 & 5.11 & & \\
\hline Beliefs & & & & & & & & \\
\hline Good & 54 & 30.68 & 50 & 28.41 & 11 & 6.25 & 0.153 & 6.69 \\
\hline Moderate & 21 & 11.93 & 27 & 15.34 & 11 & 6.25 & & \\
\hline Less & 1 & 0.57 & 0 & 0 & 1 & 0.57 & & \\
\hline $\begin{array}{l}\text { Accessibility of the } \\
\text { health facility }\end{array}$ & & & & & & & & \\
\hline Affordable & 74 & 42.05 & 76 & 43.18 & 19 & 10.80 & 0.002 & $12.64^{\star * *}$ \\
\hline Not affordable & 2 & 1.14 & 1 & 0.57 & 4 & 2.27 & & \\
\hline Health-related skills & & & & & & & & \\
\hline Good & 58 & 32.95 & 59 & 33.52 & 15 & 8.52 & 0.735 & 2.00 \\
\hline Moderate & 17 & 9.66 & 17 & 9.66 & 7 & 3.98 & & \\
\hline Less & 1 & 0.57 & 1 & 0.57 & 1 & 0.57 & & \\
\hline Peer support & & & & & & & & \\
\hline Good & 50 & 28.41 & 41 & 23.30 & 11 & 6.25 & 0.006 & $14.37^{* * *}$ \\
\hline Moderate & 23 & 13.07 & 31 & 17.61 & 6 & 3.41 & & \\
\hline Less & 3 & 1.70 & 5 & 2.84 & 6 & 3.41 & & \\
\hline Health-care support & & & & & & & & \\
\hline Good & 70 & 39.77 & 67 & 38.07 & 17 & 9.66 & 0.022 & $11.43^{\star *}$ \\
\hline Moderate & 6 & 3.41 & 5 & 2.84 & 3 & 1.70 & & \\
\hline Less & 0 & 0 & 5 & 2.84 & 3 & 1.70 & & \\
\hline
\end{tabular}


significant relationship with the prevention of HIVIAIDS transmission (Table 4).

Table 4: Multivariate analysis $(n=176)$

\begin{tabular}{|c|c|c|c|}
\hline \multirow[t]{2}{*}{ Variables } & \multicolumn{3}{|c|}{ Prevention of HIV/AIDS transmission } \\
\hline & p-value & OR & $95 \% \mathrm{Cl}$ \\
\hline \multicolumn{4}{|c|}{ Time since HIV diagnosis } \\
\hline$<1$ year & & 0.000 & \\
\hline More than 1 year & 0.193 & -0.423 & $(-1.061,0.214)$ \\
\hline \multicolumn{4}{|l|}{ Knowledge } \\
\hline Good & & 0.000 & \\
\hline Moderate & 0.002 & $1.171^{\star \star *}$ & $(0.414,1.929)$ \\
\hline Less & 0.044 & $1.448^{\star \star}$ & $(0.036,2.859)$ \\
\hline \multicolumn{4}{|c|}{ Accessibility of the health facility } \\
\hline Affordable & & 0.000 & \\
\hline Not affordable & 0.305 & 0.896 & $(-0.817,2.609)$ \\
\hline \multicolumn{4}{|l|}{ Peer support } \\
\hline Good & & 0.000 & \\
\hline Moderate & 0.716 & 0.118 & $(-0.518,0.754)$ \\
\hline Less & 0.002 & $1.902^{\star \star *}$ & $(0.721,3.082)$ \\
\hline \multicolumn{4}{|l|}{ Health-care support } \\
\hline Good & & 0.000 & \\
\hline Moderate & 0.716 & 0.118 & $(-0.518,0.754)$ \\
\hline Less & 0.002 & $1.902^{*}$ & $(0.721,3.082)$ \\
\hline
\end{tabular}

\section{Discussion}

In this study, it was found that knowledge and peer support were the most dominant factors in HIV transmission prevention behavior among MSM. Knowledge is an important factor in the prevention of HIV transmission. With good knowledge about HIV, MSM can engage in good and safe behavior related to sexual intercourse. The previous research has also shown there to be a positive relationship between knowledge and HIV transmission prevention behavior [14], [22], [23], [24], [25], [26]. In addition, with good knowledge, the respondents can find out about the prevention of HIV transmission such as the use of condoms. This shows that behavior is influenced by knowledge [10]. Knowledge is a cognitive domain that is very important in relation to the formation of one's actions if the acceptance of new behavior or the adoption of behavior is based on knowledge [11]. Good knowledge of HIV must also be possessed by the community and the individual's family. This can have an impact on the acceptance of people living with HIV (PLWH) in the community, as well as combating low stigma and discrimination [27]. Therefore, knowledge is important when it comes to preventing HIV transmission and combating stigma and discrimination. It can have an impact on improving the quality of life of PLHW.

The HIV transmission prevention behavior of MSM is also influenced by peer support. In addition, support can also come from the family. In this case, peer support is a more dominant factor because in relationships because it is very much influenced by their peers. Teenagers or MSM are closer to their peers and can talk about the problems that they are experiencing. Meanwhile, MSM cannot tell openly talk to their families due to the possibility of family rejection [28]. Interpersonal influencing factors refer to the people in their closest environment, namely, their peers. The support provided by their peers is considered due to them having a lot of experience and the potential to shape individual behavior [29]. Peer support has the potential to shape individual behavior in terms of taking action in the prevention of HIVIAIDS transmission. MSM who are members of a community will get support, guidance, and/ or advice from their peers. Peer support has benefits such as increasing one's self-confidence when managing the disease, especially HIV [30]. Peer support can be instrumental, rewarding, and informative. In this study, the majority of MSM obtained peer support through information support. The previous research has shown that the information support provided includes providing information, advice, suggestions, or feedback [22].

The reinforcement in this study shows that the knowledge of HIV is still a major factor in the HIV transmission prevention behavior of MSM and/or PLWH. In addition, this study also found that peer support is an important thing as it can have a positive influence on MSM when it comes to conducting good behavior as it can prevent HIV transmission. The role of nurses as educators can play an important role in providing good information, as well as the formation of a group of peers that can become a medium for approaching and sharing information. This is also in accordance with Green's and Kreuter theory which states that an approach through health education can result in behavior change. However, the researcher realizes that this study has the limitation of involving MSM only respondents. The development of the type of respondent can provide a more varied description and information.

\section{Conclusion}

Knowledge and peer support are the dominant factors in HIV transmission prevention behavior among MSM. Having good knowledge about HIV and being supported by cooperative peers can have a positive impact on MSM. An approach to health education through one's peers can be pursued as well as the formation of networks and groups by nurses and other health workers. Furthermore, it is hoped that the government and policy-makers in health governance will pay attention to the role of peer support as a form of media in society to form good behavior, especially among MSM and PLWH.

\section{References}

1. Bare BG, Smeltzer SC. Textbook of Medical Surgical Nursing Philadelphia, PA: Lippincott; 2010. p. 628-43. 
2. Widoyono. Penyakit Tropis Epidemiologi, Penularan, Pencegahan, dan Pemberantasan. Jakarta: Erlangga; 2011.

3. Kementrian Kesehatan RI. Laporan Perkembangan HIVIAIDS dan PIMS Triwulan 3 2018; 2018.

4. Global Information and Education on HIV and AIDS. Men Who Have Sex With Men (Msm), Hiv and Aids, Avert; 2017. https:// doi.org/10.1037/e620562007-001

5. UNAIDS, Indonesia 2018; 2018-21.

6. Cohen MS. Successful treatment of HIV eliminates sexual transmission. Lancet. 2019;393(10189):2366-7. https://doi. org/10.1016/s0140-6736(19)30701-9

PMid:31056290

7. Lou J, Cheng J, Li Y, Zhang C, Xing H, Ruan Y, et al. Comparison of different strategies for controlling HIVIAIDS spreading in MSM. Infect Dis Model. 2018;3:293-300. https:// doi.org/10.1016/j.idm.2018.10.002

PMid:30839918

8. Kusnan A, Alifariki LO, Asriati A, Binekada IM, Susanty S, Muhdar, et al. Risk factors for HIV incidence in MSM (male sex man) communities in province of Southeast Sulawesi. Enferm Clín. 2020;30 Suppl 2:80-3. https://doi.org/10.1016/j. enfcli.2019.07.037

PMid:32204262

9. Smith C, White M, Ross MW. Experience of online outreach for black MSM populations at high risk for HIV transmission. J Assoc Nurses AIDS Care. 2017;28(1):25-6. https://doi.org/10.1016/j. jana.2016.09.009 PMid:27825558

10. Green LW, Kreuter MW. Health Program Planning: An Educational and Ecological Approach. United States: McGrawHill Companies; 2005.

11. Notoatmodjo S. Promosi Kesehatan dan Perilaku Kesehatan. Jakarta: Rineka Cipta; 2013.

12. Joint United Nations Programme on HIVIAIDS, UNAIDS Data 2019 Reference; 2019.

13. Adanan. Hubungan Antara Labelling Dengan Taking Action Perilaku Berisiko Penularan HIV dan AIDS Pada Sopir Truk Berdasarkan Pendekatan AIDS Risk Reduction Model (ARRM) di Tanjung Perak Timur Surabaya; 2017. https://doi. org/10.32883/hcj.v4i3.554

14. Pratama S. Hubungan Antara Labelling dengan Taking Action Perilaku Berisiko Penularan HIV dan AIDS Pada LSL (Lelaki Suka Dengan Lelaki) Berdasarkan Pendekatan Aids Risk Reduction Model (ARRM) di Kota Surabaya 2018; 2018. https:// doi.org/10.15294/ujph.v5i3.10995

15. Basen K, Fisher T. Sexual Risk Behavior Beliefs and Self Efficacy Scales. New York: Routledge; 2010.

16. Kambu Y. Analisis Faktor-Faktor Yang Mempengaruhi Tindakan Pencegahan Penularan HIV Oleh ODHA di Sorong 2012; 2012.

17. Shively M, Smith TL, Bormann J, Gifford AL. Evaluating selfefficacy for HIV disease management skills. AIDS Behav. 2002;6:371-9.

18. Irianti I. Faktor yang Berhubungan Dengan Pemanfaatan
Pelayanan Kesehatan Petani Rumput Laut Desa Garassikang Kecamatan Bangkala Barat Kabupaten Jeneponto; 2018.

19. Puspah H. Faktor-Faktor Yang Berhubungan Dengan Pencegahan Anemia Pada Remaja Putri Berbasis Teori Lawrence Green di SMPN 3 Banjarbaru Kota Banjarbaru Kalimantan Selatan, Repos Unair; 2017. p. 67-72. https://doi. org/10.33087/jiubj.v19i1.552

20. Holliday RB. Anemia Prevention: Development of a TheoryDriven Nutrition Education Measurement, University Connection; 2011.

21. Putri M. Hubungan Peran Tenaga Kesehatan Terhadap Kepatuhan Ibu Hamil dalam Mengkonsumsi Tablet Fe 2016; 2016. https://doi.org/10.14710/jpki.11.2.100-115

22. Kurniawati ND, Wahyuni ED, Toulasik YA. Family support improves hypertensive patient drug compliance. Indian J Public Health Res Dev. 2019;10:2660-5. https://doi. org/10.5958/0976-5506.2019.02270.8

23. Wardhani PK, Shaluhiyah Z, Demartoto A. Condom Use and Smoothing Behavior in MSM in Surakarta. J Promosi Kesehat Indones. 2015;10:89-101.

24. Haffejee F, Ports KA, Mosavel M. Knowledge and attitudes about HIV infection and prevention of mother to child transmission of HIV in an urban, low income community in Durban, South Africa: Perspectives of residents and health care volunteers. Health SA Gesondheid. 2016;21:171-8. https://doi.org/10.1016/j. hsag.2016.02.001

25. Nsubuga S, Meadway J, Olupot-Olupot P. A study using knowledge, attitude and practices on the prevention of HIV-1 vertical transmission with outcomes in early infant HIV-1 diagnosis in Eastern Uganda. J Virus Erad. 2019;5(2):102-8. https://doi.org/10.1016/s2055-6640(20)30059-5 PMid:31191913

26. Irfan A, Kazmi SK, Anwar Z, Khan FM, Khan J, Arif Y, et al. Knowledge and attitude of pregnant women regarding HIV transmission, prevention and associated factors in Karachi, Pakistan-a cross-sectional study. Sex Reprod Healthc. 2019;21:46-50. https://doi.org/10.1016/j.srhc.2019.06.001 PMid:31395233

27. Sukartini T, Nursalam $\mathrm{N}$, Arifin $\mathrm{H}$. The determinants of willingness to care for people living with HIV-AIDS: A cross-sectional study in Indonesia. Health Soc Care Community. 2021;29(3):809-17. https://doi.org/10.1111/hsc.13318

28. Victoryna F, Yona S, Waluyo A. The relationship between stigma, family acceptance, peer support and stress level among HIVpositive men who have sex with men (MSM) in Medan, North Sumatera, Indonesia.EnfermClín.2019;29Suppl2:219-22.https:// doi.org/10.1016/j.enfcli.2019.04.026 PMid:31262678

29. Aune I, Dahlberg U, Ingebrigtsen O. Relational continuity as a model of care in practical midwifery studies. $\mathrm{Br} \mathrm{J}$ Midwifery. 2011;19:515-23. https://doi.org/10.12968/bjom.2011.19.8.515

30. Rajabiun S, Abridge A, Tonias C. Assesment of Peer Support Activities: Keeping Peers in Good Health and Giving Them a Better Quality of Life; 2010. 